\title{
On Recent Nationalisms in Translation Studies
}

\author{
Anthony Pym \\ The University of Melbourne/ Universitat Rovira i Virgili \\ anthony.pym@unimelb.edu.au
}

\begin{abstract}
If the intercultural were ever neatly opposed to the national as a frame for translational action and thought, then it would seem to be losing. Nationalist frames have gained new-found energy in various forms: translation is seen a weapon because nation-states support and manipulate it (Sapiro), the ethical aim of translation is to advance one's national interests and priorities (Ren and Gao), and each country's "translation capacity" can be quantified and ranked on a league table of competing nations (BFSU). Translators thus become foot-soldiers in battles to gain prestige on the world stage. Such manifestations of nationalism appear to run counter to the causes of intercultural positions and the ethics of cooperative communication between unequal parties. The need for translation nevertheless now lies more urgently in the culturally and linguistically diverse communities within and across national borders, where successful social inclusion is inseparable from the use of translation not as a weapon, but as a means of cooperation.
\end{abstract}

KEYWORDS: nationalism, translator ethics, internationalism, cooperation theory, translation theories

논문초록: 번역행위 및 사고의 프레임으로서의 상호문화주의가 민족주의와 대척점에 있는 개념이라면, 지금 상호문화주의는 민족주의에 기세가 밀리고 있는 것으로 보일 것이다. 민족주의 프레임은 다양한 형태로 새로운 동력을 얻고 있으며, 번역은 그 무 기로 인식된다. 민족국가에서 번역을 지원하고 조작(Sapiro)하고 있고, 국가의 이익과 우선순위를 증진하는 것이 번역의 윤리적 목적(Ren and Gao)이며, 서로 경쟁하는 국 가들의 리그 순위표 상에서 각국의 '번역능력(translation capacity)'을 계량화 · 순위화 
(BFSU)할 수 있기 때문이다. 이에 따라 번역사는 세계 무대에서 명성을 얻기 위한 전 투에서 보병 역할을 하게 되었다. 이러한 민족주의의 발현은 상호문화주의적 입장의 대의, 그리고 불평등한 세력 사이의 협력적 소통의 윤리에 배치되는 것으로 보인다. 그 럼에도 불구하고, 오늘날 각국의 국경 안팎에 자리한 문화적 - 언어적으로 다양한 공동 체에서 번역의 필요성은 더욱 시급해지고 있다. 이들 공동체에서 사회적 포용의 성공 여부는 번역의 활용과 불가분의 관계를 가지며, 이때 번역은 무기가 아닌 협력의 수단 으로 기능한다.

핵심어: 민족주의, 번역이론, 번역사 윤리, 국제주의, 협력이론

If I knew something that was useful to me and yet harmful to my family, I would cast it out of my mind. If I knew something that was useful for my family but was not useful for my homeland, I would seek to forget it. And if I knew something that was useful for my homeland but harmful to Europe, or useful for Europe but harmful to humanity, I would consider it a crime. (Montesquieu, 1879, pp. 157-158; my translation)

\section{Introduction}

By "nationalism" here I mean the projection of positive values on the nation or country (with or without a state), in this case as a category for organizing the way one talks about translations. As such, nationalism has been a feature of discourses on translation for at least as long as the European concept of the nation has been politically operative. It has nevertheless taken on new forms in recent years, to an extent that should be noted and questioned.

Here I am grappling with a personal problem, which may or may not be of interest to anyone else. An institution that I am associated with has dedicated considerable effort to quantifying "country-specific translation capacities" (BFSU, 2021a). This basically involves measuring all the various parts of what one might otherwise call a translation ecosystem: legislation, policies, emergency translation services, translation companies, distribution of translations, training, research, and technologies - with many further items listed at lower levels of the model, including something perhaps similar to what you and I are doing here: "the discourse system of translation 
theories with Chinese characteristics" (BFSU, 2021b). The model reportedly indicates that the United States has the greatest translation capacity in the world, followed by the United Kingdom and then China. The model would thus seem eminently useful for attracting attention and funds to the cause of translation in at least one particular country. After all, why should China ever be content with a bronze medal?

What is my problem? I am invited to welcome this initiative and the research center behind it. I am genuinely unsure of how to respond. Must all aspects of translation really be coordinated within the bounds of a single country? Is translation theory and research really just one element among many in a national capacity? Need we all be so concerned about having one country or another ranked highly in a league table, as if translation were an Olympic sport?

The problem is not particularly with China or any other nation. It is with the category of the nation as such. Is it really a good or perhaps necessary way of organizing the activities of translators, interpreters, and those who talk about translation (which will henceforth include spoken, written and audiovisual modes)?

Since the problem is by no means new, a quick survey of past nationalisms might serve to indicate that something novel might indeed be afoot.

\section{The Good of Nations}

If we temporarily regard as nations the 193 or so members of the United Nations - better described as nation-states -, we must admit that the existence of such things has proved historically useful. ${ }^{1}$ National borders are excellent ways of controlling and tracking the movement of merchandise and people (travelers have passports), of organizing the state's monopoly on violence (nations have militaries), and since borders are thus controlled and defended, nationstates are mostly appropriate for trying to control the spread of illicit drugs

1 This is a convenient, pragmatic way of identifying the kind of "nation" here associated with nationalism: an institution minimally with recognized territorial sovereignty, a declared or de facto official language, and a legal and financial regime operative over the territory. The ideological add-on that most concerns me here is the ideal of a shared culture and language of identification. 
and pandemics, for example. International causes like the climate emergency go well beyond nations, of course, but coordinated national policies still seem the best way of dealing with it. International campaigns and agreements are designed to pressure nation states; one works with the powers that be. The nation-state is also a useful dimension for participative democracy and for the official standardized languages that can ensure a degree of democratic participation. True, the nation-state is increasingly seen as being inadequate for the control of globalizing economies, although in the 2008 financial crisis, as French president Sarkozy put it at the time, multinational companies "remembered with disconcerting ease that they each had a nationality - they all lined up for hand-outs [aucune ne sest trompée de guichet!]" (my translation, 2010). The nation-state is still there when globalization goes wrong. It can invest in the public good, just as it can invest in translations, which are operative on all the various levels and dimensions that I have just attributed to the nation-state.

On the other hand, nations are not particularly good frames for language diversity. The problem could be mathematical: those 193 member nations house some 7,139 living languages, 4,065 of which have writing systems (Ethnologue, 2021). If translation is considered a fact of language difference, of working from one language to another, then it is not clear that we should really be talking about nation-states at all. The vast majority of languages are clearly not identified with nations and do not benefit from accrued national power. Virtually all our nation-states have a growing number of languages spoken within them, as the flows of migration and economic globalization feed into superdiverse cities, in some cases accompanied by policies to maintain, develop or recuperate First Nation languages. The association of one nation with one language, although eminently useful for democratic participation, is a principle that appears increasingly precarious.

I have no desire or capacity to do away with nations. I am simply concerned that their priorities should be compatible with all the other levels of human organization. Montesquieu, in the well-known passage cited above, gives us one way of handling this problem: what appears useful on each level of social organization is only ethically valid if it is not harmful on the superior level. This could be an easy solution to my problem: the calculation of a country-specific translation capacity could potentially help one nation-state and not incur harm for others; indeed, we might imagine it being eventually 
used to calculate and improve translation capacities for all countries, and thereby enhance the world translation capacity.

Problem solved? Let me consider Montesquieu's solution a just little more critically.

\section{Old Nationalisms}

My first question is epistemological. How can we know that something is harmful or beneficial for others? We would have to know quite a lot about the world beyond our immediate environment, indeed beyond our languages. This means that we have to rely enormously on translations in order to make any judgement of the kind Montesquieu proposes. So what happens if one level in the hierarchy of social organization, for example the nationstate, takes pains to control the incoming translations (what I will call here "intranslations")? Montesquieu's solution would be severely compromised.

Nationalist control over translation flows is certainly nothing new. Even before the evolution of the nation-state and the imposition of official languages, the institutions of proto-nations regularly intervened to vet what kind of knowledge could be imported. In multilingual 13th-century Castile, for instance, King Alfonso X sponsored scholarly intranslations from Arabic but made sure they said the right things: "he deleted the phrases that he considered superfluous and that were not in good Castilian; and he put in other phrases that he considered suitable; and he corrected the language himself" (Solalinde, 1915, p. 287). In the Hispanic world, that kind of intervention can be traced through the nationalized Inquisition all the way to the state censorship exercised by the Franco regime: cultural products of all kinds would be banned, cuts made, plots reframed, and translations produced to suit national ideologies. Nothing new there, not in Spain, not anywhere. As noted, the practice generally concerns messages coming into a country, the intranslations. It is part and parcel of state censorship practices, which are widespread and can be found to some extent in all climes, extending to the internalized censorship of simply avoiding expressions that are considered inappropriate.

The problem for Montesquieu's solution is obvious. If people in one country are led to believe that they stand at the pinnacle of human 
achievement, then they are unable to imagine anything they know as being harmful to anyone else. Effective control over intranslations can make people believe they belong to the world's greatest nation, a fool's paradise.

\section{Internationalist Nationalisms}

This epistemological problem can be taken one step further. If intranslations can be completely trusted as the truth of all other cultures, then one's national culture might be construed as being so superior that it should be translated into all others. This takes Montesquieu's negative ethics (basically the Hippocratic "do no harm") and converts it into a positive plan of action, this time concerning extranslations as well as intranslations.

One finds this in Wilhelm von Humboldt, in the very text where he grasps languages as diverse views of the world. Humboldt (1836) declares that the Greeks and Romans did not have "the thought of respecting a person simply as a person" (p. 22). His culture had attained that humanist insight and so it should be translated from Europe to the world:

It is a splendid privilege of our own day, to carry civilization into the remotest corners of the earth, to couple this endeavor with every undertaking, and to utilize power and means for the purpose, even apart from other ends. The operative principle here, of universal humanity, is an advance to which only our own age has truly ascended (Humboldt, 1836, p. 22; my translation, here and throughout).

And so we have secular justification for a thousand colonial projects, using "power and means" to spread the perceived virtues of modernity, sanctioned by the foremost intellectual and diplomat of the Prussian state.

It is not hard to find examples where such views have been incorporated into the theorization of translation. Most of the cases that spring to mind concern extranslations, often literary, and interestingly accompany ideologies that, like Humboldt's humanism, can be explicitly internationalist in the sense that one nation's virtues are to be extended to other nations.

An instance of internationalist nationalism might be the Franklin Book Program (Haddadian-Moghaddam, 2020), financed by the CIA in order 
to spread the ideals of the American market economy to the Middle East through the translation of selected American authors. The other side of the Cold War coin would then be internationalism of Communist countries, dedicated to the liberation of workers across the globe by translating the foundational texts of Marxist-Leninism into as many languages as could be found.

For such projects to work, effective control is required over both intranslations (so we believe in our superiority) and extranslations (so others might share in our superiority). This means controlling a lot of translators. In Soviet-bloc countries, translation theory would thus regularly include appeals to Party ideologies to which translators should be loyal. Although the Parties were first and foremost national institutions, exercising control within the bounds of the nation-state, the same ideals could be shared across nations. Baer and Schäffner (2021) trace the ethical virtues of translators adhering to such principles from the partiinost' found in Fedorov (1953) through to the Parteilichkeit in the Leipzig School of translation studies into the 1980s. They include examples like the following, found in the East German journal Fremdsprachen in 1985:

The translators and interpreters of our country stand on the side of freedom and progress. Their good work will further strengthen our republic and thus make an honorable contribution to preparations for the 11th congress of the Communist Party of the Democratic Republic of Germany (My translation and italics, as cited in Baer \& Schäffner, 2021, p. 499).

One notes here the way Marxist-Leninist principles, which are clearly internationalist, are calqued on an equally clear national frame: our country and our Party.

Not all theoretical principles were quite so up-front, since loyalty can be mixed with more technical virtues. Writing in the Soviet Union, Fedorov (1953) referred in his main theoretical text to the translator's "ideological responsibility" both to the start text and to text function, associating the latter with the need to ensure that texts with a "purely propagandistic intention" should be altered so as to achieve the desired effect (p. 198). In Socialist Slovakia, Popovič designed a "praxeology of translation" that in part evaluated the extent to which translations met "social needs", which included tracing 
"the influence of cultural policies (the Party principle) on the translation programme" (Popovič, 1975, pp. 282, 239; as cited in Špirk, 2014, p. 29). Some of these references have admittedly been photoshopped out of our discipline: the Stalinist commitment to propaganda was toned down in later editions of Fedorov's main work, and Popovičss reference to "the Party principle" did not find its way into his only translation into a West European language, Italian (Popovič, 1975/2006, p. 139). Yet the ideas are there, if you know where to look.

The theory of interpreting has not been immune to such thought. The East German state interpreter and scholar Otto Kade referred openly to the need for interpreters to exercise "partiality", described in the following terms:

Partiality in interpreting means processing the text to be interpreted from the point of view of the working class, on the basis of the Marxist-Leninist worldview. [...] Conceptual processing and logical organization, e.g. the assessment of what is important and unimportant, is not possible outside a class-based perspective and independent of a basic political-ideological stance (Kade, 1963, p. 15; as cited in Pöchhacker, 2006, p. 200; a similar example is in Baer \& Schäffner, 2021, p. 47).

Such statements are not necessarily naïve applications of coercive ideologies. The political regimes were investing directly in extensive national programs for the translation of literary texts (of direct interest to Fedorov and Popovič) and Kade was working as a head interpreter for East German institutions. In that sense, the explicitly theorized ideological principles were in fact respecting the interests of the mediators' most direct clients and, in the case of state propaganda, paying due attention to the priorities of text type and function so as to ensure that translation strategies could fulfil national purposes.

Do not believe that functionalist translation theories were ideologically neutral! And they can serve nationalist translation programs today.

\section{Totalitarian Nationalisms}

Montesquieu's solution is based on a hierarchy of social organization (self, family, homeland, Europe, humanity) that can also be thought of as concentric 
circles. Now, how do we know that those circles actually fit within each other? Can we really suppose that all family members will self-censor themselves in the same way, or that all families in a national space truly belong to the same homeland and all speak the same language? Clearly not. Families split, people migrate, nations become ethnically diverse and multilingual, to the point where relatively few people in the world are able to assume such neatly concentric circles of identity. This is the message carried in the number of languages in the world. It is also the message that can be blatantly ignored by nationalist translation theories. I note two senses in which this can happen.

The first is when there is the assumption that all discourses within a national space are bound together in a shared common purpose, such that the same interventions and ideologies are considered valid in all of them, without exception. This is what is technically meant by "fascist" discourses (the "binding together" in a fascis, a bundle), which become "totalitarian" when the one set of principles is supposed to regulate all facets of life (see Faye, 1972). This could be considered a natural perfection of the organic nation, an ideal that was exported from Europe from the late 18th century. On this view, translators will adhere to such principles simply because they are parts of a greater organic whole.

The second sense is when the translator is supposed to adhere to national principles not just as a fact of employment (we advance the interests of the nation-state as our client), but more profoundly because of birthright ("nation" comes from the Latin "natio", birth): as a citizen of the nation, one is expected to be patriotic, regardless of personal opinions. Churches, activist groups and commercial companies, which also call for adaptation to functional appropriateness, are different in that they allow for a moment of personal decision, as a fact of epiphany or employment. Birthright does not.

The surprising thing is that, when one looks closely at the various pronouncements on translation, not all of them actually deploy assumptions of common purpose. Alfonso X did not seek to vet all translations, Fedorov used a text typology where only some translations were to be propagandistic, and Popovič was explicitly espousing principles that opposed "commercial" translations, which is a backhand way of recognizing that not everything was entirely in the hands of the nation-state.

If, on the other hand, we go back to the Enlightenment ideals underlying French Neo-Classicism and German Romanticism, we find not infrequent 
assumptions that translators work to serve their language and country, assumed to be on the target side. The general ways in which this was thought about were remarkably different. As is well known, a strand of French tradition sees translators as importing into French only the best from foreign languages, while a mainstay of German Romanticism was that translators can draw on the foreign to build up German as a national language. Both approaches implicitly assumed that the languages marked out clear borders (quite naively in the case of French, and well prior to the existence of a state in the case of German) and they presupposed that the translator was on just one side of the border: the target or receiving side.

It is from this kind of implicit opposition between the French and German approaches - and in the context of the Napoleonic Wars - that we have Schleiermacher's long-standing opposition between "foreignizing" (verfremdend) and "domesticating" (verdeutschend) approaches to translation (1813/1963), calqued on a basic national opposition between "us" and "them", with nothing good happening in between. I have elsewhere (Pym, 1995) analyzed the way Schleiermacher's powerful opposition devalorizes any middle ground and is homologous with discourses in which Jews in Prussia, for example, were required to be on one side or the other. The workings of this nationalist logic are then obscured, however, when the German Romantics are seen from the perspective of French tradition in Berman (1984), where the "us" versus "them" dichotomy becomes ethnocentric French tradition opposed to exocentric Germanic foreignizing. If you like, the French national division is superimposed on the German one, effectively concealing the nationalist workings of the latter. The result of such thought is a nationalization of the classical binarism of Western translation theory, operative at least since Cicero and Horace. And that nationalized binarism has been carried through to countless translator-training institutions in our own day, where students are taught that translations can be "domesticating" or "foreignizing", as if there were a clear linguistic and cultural border separating the two.

Any translating translator knows that the opposition between domestication and foreignization fails to account for the inherent complexities of the translation process and the numerous options available. Yet the invisible national borders persist in our theories. And then, if we seek to break away from the binary and enter a plurality of translation solutions, 
we find foundational texts like Vinay and Darbelnet (1957/1972), where the typology is rich but the ideology is not: the French linguists developed their project precisely to ensure that Canadian French remained "naturally" close to the French of France, resisting contamination from English. The national borders remained the cause to be defended, this time expressed in terms of a totalitarian "spirit" (génie) of the national language.

A whole tradition of translation theory has followed suit, in many languages (Pym, 2016).

\section{Statistical Nationalisms}

Traditional translation history has surreptitiously bought into the assumption of concentric circles, presupposing that national borders are pertinent organizations of data, often without due reflection (cf. Paloposki, 2022). When, for example, Rundle (2012) proposes that translation history is part of general history, the proposition would seem entirely innocuous until one looks at the examples deployed: the study of translations under Italian Fascism contributes to (and admittedly nuances) the general history of Italian Fascism, but to reach that claim one has to assume that there were no other divisions of the world in play.

In many cases, our historians - and indeed a few nominal sociologists - are virtually obliged to assume national borders because the powers underlying those borders have constituted the basic data available. If, for example, we want to explain the various translation flows in the world, we have to know how many cultural products were translated from which language to which language. The institutions that compile those numbers are mostly national: the various controls over publishers, the national libraries, the nations that contributed to the UNESCO's Index Translationum.

Parker (2008), for example, uses a macro-economic formula to calculate the size and projected development of the translation market for all countries in the United Nations, since the prime economic data are already available. Pym et al. (2012) then use Parker's estimates to quantify how many fulltime-equivalent translators and interpreters could be working for a range of different countries, along with data on translator associations, salary scales, tax regulations, and so on. In that particular case, the national frames were 
required by the research client, the European Commission. National statistics similarly enter the calculation of global translation flows by Heilbron (1999) and Heilbron and Sapiro (2007), strangely described as sociological approaches even in the absence of anything except national numbers. As Meylaerts (2006) notes, "sociology, in particular the Bourdieu tradition, is too much linked with structures and agents that refer to national societies only" (p. 61). This is not particularly surprising when one considers the extent to which the great sociological models, from Durkheim through to Parsons, Bourdieu and Luhmann, were looking at national societies tacitly assumed to be monolingual.

Vaguely sociological literary histories nevertheless adopt the same national frames, extract a quick lesson from the numbers, then throw away the numbers. When Casanova (1999), for example, argues that world literature is structured like what Bourdieu found for literature in France, her arguments are largely based on ad-hoc lists of writers' names, each of which comes with a country and language of apparent origin. Her only possible finding is then that world literature is not so much a unified republic as it is a configuration of nations.

Something similar happens when Venuti (1995) uses national statistics to note, in the first instance, that translations account for between 3\% and 5\% of titles published in English. He then ties this to the great nationalist binarism inherited from Schleiermacher, intimating that translators in the United States and the United Kingdom are subject to the norms of domesticating ("fluent") translation. We are thus led to believe that the scandalously low percentage of translations is somehow due to the dominance of domesticating translation strategies. It is more likely that the percentages are a normal statistical consequence of the sheer size of book production in English, but that is a mere technical infelicity in the argument. By pairing national statistics with the assumption of national translation norms, Venuti brings together two of the above strands in a double-whammy nationalism that, in its descriptive moment, struggles to see beyond its initial assumptions (Cussel, 2021). To be sure, Venuti has made frequent "calls to action" in order to change the situation he describes, and those calls have been effective in drawing attention to translation and galvanizing debate, but the actual description itself remains unthinkingly nationalist. It feeds into the not infrequent claims that Western countries domesticate while Eastern countries foreignize. Translation is far more complicated than that. 
Similar to Venuti in political intent might be the work of Sapiro (2014, 2019), who broadly applies Bourdieu's categories to world literature: "translation presupposes, above all, a space of international relations formed by nation-states and linguistic groups, which are linked together through competition and rivalry" (2014, p. 32). That particular presupposition is made by Bourdieu's sociology, not particularly by all translations, and the emphasis on rivalry rather than possible cooperation is also straight out of Bourdieu's playbook. It is thanks to that assumed rivalry that Sapiro then sees translation as a potential agent of change. On the one hand, what she terms "weaponization" can be seen in the ways in which nation states invest resources in promoting themselves through extranslations (also intranslations in the case of France) as an arm of cultural policy. On the other, Sapiro, following Toury (1995), is aware that translations can have a disruptive effect, subverting the norms of literary fields and contesting established hegemonies. One of her examples is the impact of Faulkner on the French literary field in the 1930s, where translations became a weapon that could be used to bring about change. The reference to translation as a weapon is also adopted by Sicari (2020) when looking at the struggles for and against oppositional literature in the Soviet Union. Such cases make it very clear that translations cannot be reduced to expressions of nationalism. But what they also make clear is the surreptitious hegemony of national borders as deceptively natural ways of organizing thought on translation.

\section{Some Non-Western Nationalisms}

It should escape no one that all the above examples are from Western cultures and Western translation studies. Montesquieu's ethics of concentric circles is similarly Western, with a neatness and clarity that one would not expect to find in other parts of the world or indeed in more recent times. In approaching translation history in terms of postmodernist discourse, for instance, Paul Bandia (2006) does not hesitate to characterize nationstates not just as a "Eurocentric construction" but also as "modernist" and therefore "obsolete" (pp. 50-52). In short, they are no longer what we should be concerned with. If only the world were as postmodern as Bandia.

It is not too hard to find clearly national frames operative in translation 
theories and policies in non-Western countries. Thanks to colonial expansion and at least a century of cultural hegemony, the European model of the nation-state was exported around the world, including in many places where it was grossly unsuited and "nation building" was ideologically constructed as a historical mission. New words and concepts were formulated to express nationalism (cf. for example, Cao, 2021), not without difficulty and not without translation (cf. Schäfer, 2018). If there was to be a hierarchy of neatly concentric circles, a national identity would be required, and with it a national language and a national education system to foster the identity and the language. An almost natural consequence was the use of translation to build up cultural capital in the national languages and provide materials for the education systems. Translation has thus long been an instrument of nation building, often in the service of national language policies. This need not mean the imposition of monolingualism, of course. In India, for instance, the National Translation Mission describes itself as a "Government of India initiative to make knowledge texts accessible in all Indian languages through translation" (ntm.org.in, italics mine). Such initiatives indicate that the nationstate is not entirely obsolete.

Rather than postmodern plurality, some cases of non-Western nationalism appear to be emerging with a unity of purpose and a clarity of principle that could indeed surpass most European statements on role and mission of translation. Here I just give a few recent examples.

In the context of Pakistan, Habib (2020) calls for a "national translation theory" that is explicitly based on national pride and moves away from the hegemony of English as the (post)colonial lingua franca. Translations into Urdu, in this case, should build up the language (as was the case of the German Romantics) and should include translator interventions that support the cause of national pride (Habib, 2020, pp. 62-63). An example is given of an English text that has passages expounding the superiority of Europeans. Those passages are omitted in a nationalist translation into Urdu, so no one will know that such reprobate arguments were ever formulated. As for translations from Urdu into English, they "should contain the cultural richness through the use of footnotes / explanatory notes / explicitation by allowing objective inclusion of national/regional references to the original (source) language culture" (Habib, 2020, p. 61). So we would have judicious deletion on the side of intranslations, and explanatory expansion in extranslations. In terms of the 
great binarism, domesticate what comes in and foreignize what goes out.

A more developed nationalist approach is found in the National Translation Program (in Chinese more like a "country-specific translation practice", 国家翻译实践) expounded in Ren and Gao (2015a). This concerns not just national pride but also the theorization of an entire translation system that is described as being autopoietic (it has "spontaneity" 自发性), autonomous (自主性) and operating in the interest of the nation (self-interest, 自利性). The priorities of this self-interest are made clear in the way an ethics of cooperation is overtly refuted: “在国家翻译实践的内部合作中，合作各方的 利益是一致的，都是国家的利益，因此不存在协调 各方利益的问题” (Ren \& Gao, 2015b, p. 108), which might translate as: "In the internal cooperation of the national translation practice, the interests of the cooperating parties are the same, since they are the interests of the country, and therefore there is no question of reconciling the interests of all parties." This means that the kind of win-win ethics of cooperation proposed by Pym (2012) is explicitly rejected, simply because it is not needed. Nor is there any theoretical problem with the translator's subjectivity and agency, since both are by definition subservient to the national interest. Such a position does indeed remove many philosophical and sociological problems.

The principles of the National Translation Program have consequences for both intranslations and extranslations. A contemporary example of intranslations might be the way the Chinese official news agency Reference News selects, reframes and translates stories on WeChat so as to present a positive image of China (Zeng \& $\mathrm{Li}, 2021$ ). The Chinese reader is led to believe that foreigners have a globally positive image of China. As for extranslations, Ren (2018) proposes that literary fiction should be translated in such a way as to ensure a positive image of Chinese history, particularly with respect to the history of the Communist Party. Translators should have no qualms about omitting passages and aspects that are considered unsuitable. The strategy is called "extraction" but amounts to censorial omission and reframing so as to depict the perfect revolutionary hero. In Ren's analyses of Sidney Shapiro's ideological adaptations of "red classics", changes are found to have been made not just in order to sanitize China's revolutionary past but also in order to accommodate readers' habits (Ren, 2017; Ren \& Zho, 2021). This might seem a version of traditional domesticating or functionalist strategies, but in this case the interventions are also motivated by the translator's prior commitment 
to the Chinese national cause. Although born American, Shapiro became a citizen of the People's Republic in 1963 and worked for Beijing's Foreign Language Press. As Ren makes clear, a few non-nationals can be trusted if and when they are truly committed to the cause.

The principles of the National Translation Program are extremely coherent within themselves. They would seem to dovetail with the evaluation of a 'Country-Specific Translation and Interpretation Capacity', which was my initial problem here. One notes, for example, that the Capacity model only quantifies translations between Chinese and "foreign languages"; it does not appear to include translations involving minority languages or varieties of Chinese (BFSU, 2021c, note 6). Why this clear focus, not just on one country but also on one language as the symbolic unification of the nation? It could be because the nation-state is simply the most efficient level on which to plan and fund undertakings like emergency translation services and translatortraining programs, or to indeed produce translations on the scale and for the same reasons one manufactures tractors - because the country needs ideological soils to be tilled. Then again, could the "one country" focus also be legitimized as just one level among several, as in Montesquieu's circles, such that the development of a national capacity could service some higher, non-country-specific goals? There is no inkling of this in the principles so far expounded, no trace of the internationalism that once marked the MarxistLeninist ideals of earlier translation programs.

The peculiar thing here is that the explicit rejection of cooperation as win-win interaction would seem to contradict references made to that same model in a series of statements on Chinese foreign relations. From at least 2014, Xi Jinping refers to "win-win cooperation" repeatedly, for example in speeches like "Asia-Pacific Partnership of Mutual Trust, Inclusiveness, Cooperation and Win-Win Progress" or "Build a Win-Win, Equitable and Balanced Governance Mechanism on Climate Change" (these and many other cooperation-based speeches are in Xi, 2017). Much as one would like to accept that all Chinese translation agents always agree on everything within one country, should that miraculous consensus really discount the search for winwin cooperation through translations between one country and the rest of the world? There does seem to be an intellectual gap to fill.

In their survey of Soviet-inspired translation principles, Baer and Schäffner (2021, p. 53) ask, "To what extent can a translator working under 
socialism be compared to an activist translator?". And when we look at the ideals of the National Translation Program, where all is subordinate to the one national cause, we do indeed find a rhetoric of engagement and commitment quite close to that expounded in the name of activist translation and interpreting (see for example Boéri \& Maier, 2010; Boéri \& Delgado Luchner, 2021), which similarly rejects the cooperation model (apparently on the mistaken belief that cooperation presupposes neutrality). One might not be too surprised to find a nationalist translation program, a country-specific inventory and activist translators becoming natural allies.

So much for a few of the newer nationalisms on offer.

\section{The Bad of Nationalism}

It is common enough to distinguish between good and bad nationalisms. Sometimes the good one is ours, while the bad ones belong to foreigners (cf. Liu et al., 2021). On other occasions, a good nationalist cause might be defended in the interests of fostering cultural diversity against a bad nationalism that hides diversity (cf. Pym, 1991 on the use of "national" to describe stateless nations such as Catalonia). But if you look closely, perhaps around the edges or under the carpets of the official histories, every culture has somewhere in its past at least one example of excessive exclusionary zeal, when cries of "my country (or family, tribe, clan, gender, class) right or wrong" led to regrettable outcomes. Alfonso X of Castile, dubbed "The Learned" because of his sponsoring of translations from Arabic, drew up a system of unified weights and measures for his kingdoms, which might be positive nationalism, but then caused runaway inflation, turned on his Jewish intermediaries, and was violently deposed by his son, none of which was particularly positive. One should remember both the good and the bad of history, not just the translations.

Here I confess a very Eurocentric bias, for which I can only beg forgiveness. The excesses of nationalism are of particular resonance to any scholar of European history, still haunted by the excesses of a socialism that from the 1930s proclaimed itself national, incorporated a discourse of revenge for prior national humiliation, required rapid economic growth to keep its populace in step, found long-term cultural pride in a very distant and 
falsely homogenized ethnic past, projected further pride through the idea of its own invincible longevity, recuperated or annexed territories on the basis of past history and ethnicity, and sent cultural and religious minorities into concentration camps, with the implicit support of its people. A European does not easily forget such historical lessons; one remembers the bad of nationalism and becomes very wary of it.

Largely because of that anxiety, I have attempted to think about translation in terms of something quite different from Montesquieu's negative hierarchy. Let me briefly take stock of the position from whence I speak.

Years ago, I proposed that the values of cultural specificity should be recognized but not be ranked higher than shared criteria for effective and ethical communication (Pym, 1993a, 1993b). That sounds rather like Montesquieu: do no harm to the higher level. But I also argued, and still argue, that interculturality is anterior to the description of cultural specificity, that our thinking should account for the primacy of change rather than the stability of borders, and that translation presupposes fundamental alterity, not the sameness that might be projected by a model where everyone thinks the same way within any nation. Those things are not in Montesquieu's circles. I thus tried to turn models of national or cultural specificity on their head: rather stand at the origin of messages, a culture is what distorts transmission from translation to translation (Pym, 1993b). A little later (Pym, 2003), I started to insist that translation creates networks that move across languages and through time incrementally, with no need at all to respect national borders: the points of translation define their own configuration of geography and history. So when, for instance, I opposed a boycott of translation scholars working in Israeli universities, it was because of the nationalist principles involved (the assumption that the scholars were all subservient to the nation-state), not because I know anything special about the territories concerned.

Looking back now, little could be further from my thinking than respect for national borders! Nothing could be more foreign to my thinking that Montesquieu's concentric circles and the conservatism of doing no harm! Almost all my basic research these days is on translation and interpreting for the culturally and linguistically diverse communities within a country of immigrants, where the nation-state is certainly one level of policymaking but has no particular importance beyond that.

So how did I reply to the request to welcome the project on "country- 
specific translation capacities"? Cooperation first means finding points of mutual benefit and working from there - only turn your back when there is no good to be expected. So I cobbled together a speech on the historical role of great institutional translation projects: the Buddhist sutras into Chinese, the Baghdad translations from Greek and Syriac, the Toledan translations from Arabic - the kinds of projects that can have an impact on history. All of that is quite normal in speeches on translation; none of the examples involves anything like a country-specific translation capacity, but who would notice? And then one negotiates with the powers that be. Here is the end of that welcoming speech:

The world owes much to the translators engaged in such activities, but it also owes a great deal to the social and cultural support that enabled the translators, both written and spoken, to exercise their art in the service of cross-cultural understanding. The major translation activities have never responded to market criteria.

Translators and interpreters need to be trusted in order to carry out their work. And their trustworthiness comes from rigorous training that is rewarded with social respect. Both those sides are needed from our institutions. And then, of course, translators and interpreters need the trust and respect of those who read and listen to them, downstream, away from the institutional fold. That direction, the outward gaze, the real-world reception of translated discourse, also needs attention. What we learn about one country should help others as well.

\section{A Conclusion}

I have tried to survey the various nationalisms that inform translation studies. I have related some of the most recent back to a few that have long been entrenched, indeed that have become so common and widespread as to be virtually invisible. When we talk loosely about "domesticating" versus "foreignizing", we are recycling what was a division between nations; when we proclaim the virtues of "functionalism", we are using thought that served nationalist ideologies; when we draw on statistics for translation flows, we are again recycling the categories of the nation state, often unthinkingly. 
In making these connections, I am far from neutral. My purpose is to make you aware of those nationalisms and to invite you to question them. To some extent, any translation scholar may indeed say that the national frame is pertinent to translation because the nation state is already active within translation practice: there are subsidies and prizes for translations; national training programs are in operation; translation is attached to various competitive causes for national pride. To the extent that the nation is thus somehow within the object of study, it will inevitably appear somewhere in the ways we study. That said, though, an open empirical attitude can reveal many alternative categories that are equally in play, particularly in the often hidden multilingualism of our societies, in the myriad encounters set up by the movements of migration and capital, in the complicating roles of indirect translation, retranslation and intralingual translation, and in the many ways in which translation blends into intercultural mediation, for example.

Once one sees beyond the nationalist blinkers, there is a far richer world waiting to be explored.

\section{References}

Baer, Brian James and Christine Schäffner. (2021). Ethics in Socialist translation theories. In Nike Pokorn \& Kaisa Koskinen (Eds.), Translation and Ethics (pp. 42-57). Routledge.

Bandia, Paul F. (2006). The impact of postmodern discourse on the history of translation. In Georges L. Bastin \& Paul F. Bandia (Eds.), Charting the Future of Translation History (pp. 45-58). University of Ottawa Press.

Berman, Antoine. (1984). Lépreuve de l'étranger: culture et traduction dans l'Allemagne romantique: Herder, Goethe, Schlegel, Novalis, Humboldt, Schleiermacher, Hölderlin [The trial/test/experience of the foreign: Culture and translation in German romanticism]. Gallimard.

BFSU (Beijing Foreign Studies University). (2021a). BFSU launches research centre for country-specific translation and interpretation capacity. https://80.bfsu.edu.cn/en/ archives/696

BFSU (Beijing Foreign Studies University). (2021b). BFSU unveils translation capacity indexes of countries and Chinese universities. https://80.bfsu.edu.cn/en/archives/710

BFSU (Beijing Foreign Studies University). (2021c). Běi wài shǒufā quánqiú guójiā fānyì nénglì zhǐshù hé zhōngguó dàxué fānyì nénglì zhǐshù [Beiwai begins 
global national translation competency index and Chinese university translation competency index]. https://mp.weixin.qq.com/s/JD4jCvsjNXHNMpEU2ucElA.

Boéri, Julie and Carmen Delgado Luchner. (2021). The ethics of activist translation and interpreting. In Kaisa Koskinen \& Nike K. Pokorn (Eds.), The Routledge Handbook of Translation and Ethics (pp. 245-261). Routledge.

Boéri, Julie and Carol Maier (Eds.). (2010). Compromiso social y traducción/interpretación, Translation/Interpreting and Social Activism. ECOS.

Cao, Qing. (2021). Translating "nation" in late Qing China. The discourse and power of nation in the remaking of Chinese society, 1895-1911. In Ali Almanna \& Chonglong Gu (Eds.), Translation as a Set of Frames. Ideology, Power, Discourse, Identity \& Representation (pp. 193-208). Routledge.

Casanova, Pascale. (1999). La République mondial des lettres [The world republic of letters]. Seuil.

Cussel, Mattea. (2021). Methodological nationalism in translation studies. A critique. Translation and Interpreting Studies, 16(1), 1-18.

Ethnologue. (2021). How Many Languages are There in the World? (24th ed.). https://www. ethnologue.com/guides/how-many-languages

Faye, Jean-Pierre. (1972). Langages totalitaires: Critique de la raison narrative, léconomie narrative [Totalitarian languages: Critique of narrative reason, narrative economy]. Hermann.

Fedorov, Andrey V. (1953). Vvedenie v teoriju perevoda [Introduction to the theory of translation]. Literatury na inostrannykh yazykakh.

Habib, Muhammad Saleh. (2020). The need for a "National Translation Theory" in the Pakistani academic discourse. Journal of English Language, Literature and Education, 1(4), 59-64.

Haddadian-Moghaddam, Esmaeil. (2020). The cultural Cold War in the Middle East. William Faulkner and Franklin Book Programs. Translation and Interpreting Studies, 15(3), 441463.

Heilbron, Johan. (1999). Towards a sociology of translation: Book translations as a cultural world-system. European Journal of Social Theory, 2(4), 429-444. https://doi. org/10.1177/136843199002004002

Heilbron, Johan and Gisèle Sapiro. (2007). Outline for a sociology of translation: Current issues and future prospects. In Michaela Wolf \& Alexandra Fukari (Eds.), Constructing a Sociology of Translation (pp. 93-107). Benjamins.

Humboldt, Wilhelm von. (1836). Über die Verschiedenheit des menschlichen Sprachbaues und ihren Einfluss auf die geistige Entwickelung des Menschengeschlechts [On the differences 
in human language-structure and their influence on the intellectual development of humanity]. Druckerei der Königlichen Akademie der Wissenschaften.

Kade, Otto. (1963). Der Dolmetschvorgang und die Notation [Interpreting procedure and note-taking]. Fremdsprachen, 1963(1), 12-20.

Liu, Fengguang, Dan Han, Daniel Z. Kádár and Juliane House. (2021). The expressions “(M) minzu-zhuyi" and "Nationalism": A contrastive pragmatic analysis. Journal of Pragmatics, 174, 168-178.

Meylaerts, Reine. (2006). Conceptualizing the translator as a historical subject in multilingual environments. A challenge for Descriptive Translation Studies?. In Georges L. Bastin \& Paul F. Bandia (Eds.), Charting the Future of Translation History (pp. 59-80). University of Ottawa Press.

Montesquieu, Charles de Secondat. (1879). Portrait de Montesquieu par lui-même [Portrait of Montesquieu by himself]. In Édouard Laboulaye (Ed.), Euvres completes [Complete works] (Vol. 7, pp. 150-158). Garnier.

Paloposki, Outi. (2022). National histories of translation. In Christopher Rundle (Ed.), The Routledge handbook of translation history (pp. 70-85). Routledge.

Parker, Philip M. (2008). The 2009-2014 World Outlook for Translation and Interpretation Services. ICON Group International.

Pöchhacker, Franz. (2006). Interpreters and ideology: From "between” to "within". Across Languages and Cultures, 7(2), 191-207.

Popovič, Anton. (1975). Teória umeleckého prekladu: Aspekty textu a literárnej metakomunikácie [Theory of artistic translation: Aspects of text and literary metacommunication]. Tatran.

Popovič, Anton. (1975/2006). The Theory of Artistic Translation. Textual Aspects and Literary Metacommunication: The science of translation, Methodological aspects: Translation communication (Daniela Laudani, Trans.). Hoepli.

Pym, Anthony. (2016). Translation Solutions for Many Languages - Histories of a Flawed Dream. Bloomsbury.

Pym, Anthony. (2012). On Translator Ethics. Principles for Mediation between Cultures. John Benjamins.

Pym, Anthony. (2003). Alternatives to borders in translation theory. In Susan Petrilli (Ed.), Translation Translation (pp. 451-463). Rodopi.

Pym, Anthony. (1995). Schleiermacher and the problem of blendlinge. Translation and Literature, 4(1), 5-30.

Pym, Anthony. (1993a). Coming to terms with and against nationalist cultural specificity. Notes for an ethos of translation studies. Folia Translatologica, 2, 49-69.

Pym, Anthony. (1993b). Why translation conventions should be intercultural rather than 
culture-specific. An alternative basic-link model. Parallèles: Cahiers de l'École de Traduction et d'Interprétation de Genève, 15, 60-68.

Pym, Anthony. (1992). Translational ethics and the recognition of stateless nations. Fremdsprachen. 4, 31-35.

Pym, Anthony, François Grin, Claudio Sfreddo and Andy L. J. Chan. (2012). The Status of the Translation Profession in the European Union. European Commission.

Ren Dongsheng and Gao Yuxia. (2015a). A preliminary study on national translation practice. Chinese Foreign Languages, 3, 79-85.

Ren Dongsheng and Gao Yuxia. (2015b). National translation program: A new concept. Foreign Languages in China, 3, 92-97.

Ren Dongsheng. (2018). "Cuì yì" zhī biàn [On "extraction”], Journal of PLA University of Foreign Languages, 41(4), 16-20.

Ren Dongsheng and Zho Hongyu. (2021). An analysis of extractive translation in Sidney Shapiro's English version of Ping Yuan Lie Huo from the perspective of cognitive narratology. Journal of PLA University of Foreign Languages, 44(4), 125-160.

Rundle, Christopher. (2012). Translation as an approach to history. Translation Studies, 5(2), 232-240.

Sapiro, Gisèle. (2019). Translation and translation as a weapon. Oxford Research Encyclopedia of Literature. https://doi.org/10.1093/acrefore/9780190201098.013.942

Sapiro, Gisèle. (2014). Translation as a weapon in the struggle against cultural hegemony in the era of globalization. Bibliodiversity, 3, 31-40. https://www.alliance-editeurs.org/IMG/pdf/ bibliodiversity_3_sapiro.pdf

Sarkozy, Nicholas. (2010, Jan 27). Déclaration sur la régulation du capitalisme mondialisée [Declaration on the regulation of globalized capitalism], Vie publique. https://www.viepublique.fr/discours/178033-declaration-de-m-nicolas-sarkozy-president-de-la-republiquesur-la-re

Schäfer, Dagmar. (2018). Translation history, knowledge and nation-building in China. In SueAnn Harding \& Ovidi Carbonell Cortés (Eds.), The Routledge Handbook of Translation and Culture (pp. 134-153). Routledge.

Schleiermacher, Friedrich. (1813/1963). Ueber die verschiedenen Methoden des Uebersezens [On the different methods of translating]. In Hans J. Störig (Ed.), Das Problem des Übersetzens [The problem of translating] (pp. 38-70). Wissenschaftliche Buchgesellschaft.

Sicari, Ilaria. (2020). Paratext as weapon. The role of Soviet criticism in the cultural Cold War, Translation and Interpreting Studies, 15(3), 354-379.

Solalinde, Antonio G. (1915). Intervención de Alfonso X en la redacción de sus obras [The intervention of Alfonso X in the drafting of his works], Revista de Filología Española, 2, 
$283-288$

Špirk, Jaroslav. (2014). Indirect Translations and Non-translation: The (Fateful) Adventures of Czech Literature in 20th-century Portugal. Cambridge Scholars Publishers.

Toury, Gideon. (1995). Descriptive Translation Studies and Beyond. John Benjamins.

Venuti, Lawrence. (1995). The Translator's Invisibility. A History of Translation. Routledge.

Vinay, Jean-Paul and Jean Darbelnet. (1958/1972). Stylistique comparée du français et de langlais: méthode de traduction [Comparative stylistics of French and English: Translation method]. Didier.

Xi, Jinping. (2017). The Governance of China. Foreign Language Press.

Zeng, Weixin and Dechao Li. (2021). Presenting China's image through the translation of comments: A case study of the WeChat subscription account of Reference News. Perspectives. https://doi.org/10.1080/0907676X.2021.1960397

\section{Professional Profile}

Anthony Pym is Professor of Translation Studies at the University of Melbourne and Distinguished Professor of Translation and Intercultural Studies at Rovira i Virgili University in Tarragona, Spain. He holds a PhD in Sociology from the École des Hautes Études en Sciences Sociales, Paris. He has authored or edited 29 books and more than 220 articles in the field of translation and intercultural studies. He has generally worked on sociological approaches to translation and interpreting, although his current teaching is in the area of translation technologies and translation process studies. 